\title{
Reasons for University Students' Violence in Jordan
}

\author{
Yazid Isa Alshoraty ${ }^{1}$ \\ ${ }^{1}$ Faculty of Educational Sciences, The Hashemite University, Jordan \\ Correspondence: Yazid Isa Alshoraty, Faculty of Educational Sciences, The Hashemite University, Jordan. \\ E-mail: ysoraty@hotmail.com
}

$\begin{array}{lc}\text { Received: January 4, } 2015 & \text { Accepted: May 19, } 2015 \quad \text { Online Published: September 28, } 2015 \\ \text { doi:10.5539/ies.v8n10p150 } & \text { URL: http://dx.doi.org/10.5539/ies.v8n10p150 }\end{array}$

\begin{abstract}
The aim of this study was to examine the reasons for students' violence at Jordanian Universities from the viewpoint of the Hashemite University students. The sample consisted of 521 male and female students, chosen randomly. To collect data, the researcher designed a three- domain questionnaire. The findings of the study revealed that the most important reasons for violence were the reasons related to students (weak commitment to Islamic values, weak resort to psychological and educational counseling, forming student groups on the basis of kinship and areas, and student frustration caused by low grades), then the reasons related to society (defending the honor of family or tribe, wrong socialization, tribal support for students who resort to violence, prevalence of the culture of tribal solidarity, the great importance given to the size of the family or tribe, and pressure of some officials and influential people to reduce punishments imposed on students who resort to violence), and finally the reasons related to universities (policy of exceptions in university admissions, lack of concentration on skills of critical thinking and problem solving, weak culture of dialogue, and lack of concentration on the values of tolerance and forgiveness). Also, the results showed that there were no differences in the students' perception of the reasons for of university violence due to their sex, college, academic year and grade point average.
\end{abstract}

Keywords: university violence, reasons, students, Jordan

\section{Introduction}

The World Health Organization defined violence as "the intentional use of force or power, threatened or actual, against oneself, another person, or against a group or community, which either results in, or has a highly likelihood of resulting in injury, death, psychological harm, mal development, or deprivation" (Carr, 2005, p. 3).

Violence swept many world universities, colleges and schools, to an extent that the university environment in many cases became peaceless, dangerous, and unsecure. For instance, in the United State of America, most aspects of violence, spread on the campuses of many of its universities. University violence became a serious problem and an important area of enquiry and investigation with which researchers dealt (Wessler \& Moss, 2001).

University violence has negative and grave consequences, for it undermines the educational mission of universities, makes students and instructors live in an atmosphere of anxiety, tension and fear, hinders the natural and sound students' development and growth, leaves bad effects on individuals, universities, and societies, because it endangers campus safety, weakens national unity, distorts the reputation of higher education institutions, causes casualties and injuries, or perhaps death, and damages the facilities of universities (Wessler \& Moss, 2001; Roark 1987). Pezza and Pellotti (1995) added the following harmful influences of university violence on victims: weakening their self-esteem, identity, and self-confidence, reducing-their sense of self-control, making them feels guilty, and lose concentration.

University violence has hit most campuses of Jordanian public and private universities, taking mainly the form of students' fight, and resulting in serious human and material losses. Many fights started on the individual level, and then took family, or tribal dimensions. So, this dangerous phenomenon deserves study and investigation to reach proper solutions for it. The first step towards putting an end to it, is exploring its causes.

University violence in Jordan has recently escalated quantitatively and qualitatively. According to Al-Jundi (2014), from 2010 to 2013, there were 296 fights on Jordanian universities' campuses, in which 3999 students were involved, and which led to 7 fatalities, 193 injuries, and heavy property losses. The results of a study conducted by (Albadayneh et al., 2008) showed that one third of the Jordanian university students participated in 
fights, about two thirds of them witnessed fights, and more than two thirds of them believed that university students' violence was a dangerous social problem, on which research should concentrate. So, this study investigates the reasons for university students' violence in Jordan from the perspectives of the Hashemite University students, through answering the following questions:

1) What are the reasons for university students' violence in Jordan from the Hashemite University students' perspectives?

2) Are there significant differences in the Hashemite University students' perception of the reasons for university violence due to their sex, college, grade point average and university year?

The significance of the study lies in the following points:

- It deals with a serious problem that has hazardous effects on individuals, educational institutions and society.

- It explores the reasons for university students' violence in Jordan, without which solutions for it cannot be reached.

- Only few studies were conducted at the Hashemite University concerning the topic of this study.

\section{Review of Literature}

A number of scholars and researchers laid emphasis on university violence.

Almakhreez (2006) focused on the degree of university students' violence spread, in addition to its causes and solutions. His study included three universities: The university of Jordan, Yarmouk, and Muta. The main results of this study were:

1) The university students' violence spread in a medium degree.

2) The main reasons for university students' violence were: the reasons related to faculty members, then the reasons related to university policies and administration, then the social and psychological reasons, and finally the political reasons.

The most common methods used by university administrations to deal with university violence were: punishing students, forming investigation committees and avoiding problems. Whereas, counseling, increasing awareness, and listening to students' suggestions and opinions were the least commonly used methods.

Alrawajfeh (2007) found that the reasons for university violence in Jordan were:

- The social and economic reasons: such as social or tribal bigotry, misunderstanding of tribalism, weak family ties, wrong socialization and unemployment.

- The political reasons such as: political affiliation and fanaticism, and elections of student unions and clubs.

- The academic reasons: such as weak achievement that leads to students' frustration.

Ziadat (2007) concentrated on the reasons for university students' riot from the viewpoints of Yarmouk University students. He pointed out that eleven reasons, out of thirteen, were related to universities' administrations. Among the main reason, he found, were:

- Misconceptions about tribalism.

- Misunderstanding of democracy.

- Allowing individuals who were not students to be on campus.

- The spread of favoritism in applying laws and decisions of universities.

- Ambiguity in university security responsibilities.

- University administrations' lenience towards students who were involved in violence, riot and troubles.

Khamash, Hamdy, and Haddad (2007) came to the conclusions that the factors which contributed to student violence at the University of Jordan were: individual, or personal, or private fights, kinship fanaticism, personal differences, bad education, leisure time, and lack of hard study.

Alhawamdeh (2009) conducted a study that covered six public and private Jordanian universities about students' violence, in which he used a questionnaire and an interview. He concluded that the main reasons for students' violence were: excessive repression, focusing on academic sides and neglecting building up student's personality, family bigotry, lack of student's adaptation with university life, loneliness and depression, inequality in university laws' application, leisure time, and instructors' provocations to students. 
Albadayneh et al. (2008) prepared a study which covered nineteen public and private universities in Jordan. The results showed that the main reasons for student violence were: personal differences, harassing female students, and self-defense.

Mahafza (2014) found out that the causes of university students' violence in Jordan were:

- Enrollment of students in universities with low grades in high school.

- Poor investment of free time, and lack of extra-curricular activities.

- 3 High competitions among students during elections time.

- Students' perception of university rules and regulations as unjust.

- Fanaticism to tribes, relatives, and friends.

- Weak university students' moral and religious commitment.

Roark (1987) revealed that the main reasons for university violence in America were:

- The new university environment which causes stress and tension as a result of making students away from direct parental supervision, and putting them under peer pressure.

- The societal culture which sometimes legitimizes violence and force.

- Sexual abuse.

- Alcohol: many violent acts occur while persons are under the influence of alcohol.

- Prejudice, which means not perceiving others to be of equal value as oneself.

- Domination and force abuse.

- Socializing males to be aggressive, and females to be submissive.

Miller, Hemenway, and Wechsler (1999) made clear in a study that the students carrying weapons were more inclined to violence than others.

Marcus et al. (2000) focused on student violence at University of Maryland. They discovered that $32.7 \%$ of males and $17.3 \%$ of females were involved in at least one physical fight in the last six months, the state of $9 \%$ of them required medical treatment, and alcohol drinking was the cause of $40 \%$ of violence cases.

Kaplowitz and Campo (2004) showed that the main reason for university students' violence in America was objecting to, or protesting against putting restrictions on alcohol drinking.

The review of literature showed that although university violence in Jordan is escalating, the studies about it are still limited. Also, most of the studies that focused on university violence have not covered the Hashemite University. So, this study comes in response to the need for conducting more studies about this important topic, and for including the Hashemite University students in this regard.

\section{Method}

The researcher used the descriptive analytic method due to its suitability to the nature of the study. The population of the study consisted of 18764 students, enrolled in the Hashemite University in Jordan in the first semester of 2010/2011. The sample of the study consisted of 410 male and female, randomly chosen, students. They were requested to fill out a questionnaire, of which only 401 copies were properly completed. This is illustrated in table one 
Table 1. Distribution of the study sample's members based on their variables

\begin{tabular}{|c|c|c|c|c|c|c|}
\hline \multirow{2}{*}{1.} & \multirow{2}{*}{ College } & Human & \multicolumn{3}{|c|}{ Scientific } & Total \\
\hline & & 267 & \multicolumn{3}{|c|}{254} & 521 \\
\hline \multirow{2}{*}{2.} & \multirow{2}{*}{ Sex } & Males & & Females & & \multirow{2}{*}{521} \\
\hline & & 183 & & 338 & & \\
\hline \multirow{2}{*}{3.} & \multirow{2}{*}{ University Year } & First & Second & Third & Fourth & \multirow{2}{*}{521} \\
\hline & & 153 & 205 & 75 & 28 & \\
\hline \multirow{2}{*}{4.} & \multirow{2}{*}{ GPA } & Less than 2 & 2-Less than 3 & & & \multirow{2}{*}{521} \\
\hline & & 92 & 250 & & & \\
\hline
\end{tabular}

To achieve the aim of his study, the researcher designed a questionnaire, which consisted of 36 items representing the possible reasons for university students' violence in Jordan, organized in three domains: reasons related to students, reasons related to society and reasons related to universities. Each item required choosing one of the following responses based on Likert's five grading point-scale: full agreement (5), agreement (4), neutrality (3), disagreement (2) full disagreement (1). The means of the evaluation of the study sample members to the questionnaire items were as follows: $(1-2.33)=$ low, $(2.34-3.67)=$ medium, $(3.68-5)=$ high.

To guarantee the validity of the questionnaire, the researcher presented it to eleven referees and experts, working at the Faculty of Educational Sciences at the Hashemite University. Based on their comments and viewpoints, the researcher deleted four items out of 40 , and made some language and typing corrections.

To ensure the reliability of the instrument of this study, the test-retest method was used. The researcher applied it to a sample of 50 students of the study population. Then, it was reapplied to the same sample, ten days later. The coefficient was $(76 \%)$, which was considered to be suitable for this kind of studies.

\section{Results and Discussion}

To explore the reasons for university students' violence in Jordan from the Hashemite University students' perspectives, the means and standard deviations of the items of the three domains were found. Then, the items were arranged in a descending order depending on their means. The results were summarized and shown in (Tables 2) which showed means and standard deviations of the domains of the questionnaire, and (Table 3) which showed the most important reasons for university students' violence.

Table 2. Means and standard deviations of the domains of the questionnaire

\begin{tabular}{lccc}
\hline No. & Domain & Mean & Standard Deviation \\
\hline 1 & $\begin{array}{c}\text { Reasons related } \\
\text { students }\end{array}$ & 3.996 & .50 \\
2 & $\begin{array}{c}\text { Reasons related to } \\
\text { society } \\
\text { Reasons related to } \\
\text { universities }\end{array}$ & .983 & .584 \\
3 & 3.46 & .625 \\
\hline
\end{tabular}

Table 2 indicated that the reasons related to students accounted for the highest mean (3.996), followed by the reasons related to society with (3.19) mean, and finally the reasons related to universities with (3.46) mean. The first two domains represented reasons with high importance, whereas the third one represented reasons with medium importance, this result showed that students and society were the main sources of university violence. This was due to the fact that students in all acts of university violence were the aggressors and the victims. They were the problem and the solution. Most reasons for university violence were attributed to students. But the responsibility of society for university violence should not be ignored because students are highly affected by their society and environment in this regard. On the other hand instead of playing a constructive and purifying mission in dealing with violence, universities performed a destructive and reproductive role. 
Table 3. Means and standard deviations of the sample members' perception of the reasons for university violence

\begin{tabular}{|c|c|c|c|c|c|}
\hline No. & Reason & Mean & $\begin{array}{l}\text { Standard } \\
\text { Deviation }\end{array}$ & Domain & $\begin{array}{c}\text { Degree of } \\
\text { importance }\end{array}$ \\
\hline 1 & $\begin{array}{l}\text { Students' } \\
\text { bigotry to their } \\
\text { tribes and } \\
\text { areas }\end{array}$ & 4.48 & .85 & Students' & High \\
\hline 2 & $\begin{array}{l}\text { Weak } \\
\text { commitment } \\
\text { to Islamic } \\
\text { values }\end{array}$ & 4.4 & .86 & Students' & High \\
\hline 3 & $\begin{array}{c}\text { Weak resort to } \\
\text { psychological } \\
\text { and } \\
\text { educational } \\
\text { counseling }\end{array}$ & 4.21 & .87 & Students' & High \\
\hline 4 & $\begin{array}{l}\text { Defending the } \\
\text { honor of } \\
\text { family or tribe }\end{array}$ & 4.20 & 1 & Society's & High \\
\hline 5 & $\begin{array}{c}\text { Wrong } \\
\text { socialization }\end{array}$ & 4.18 & .9 & Society's & High \\
\hline 6 & $\begin{array}{l}\text { Tribal support } \\
\text { for students } \\
\text { who resort to } \\
\text { violence }\end{array}$ & 4.18 & .98 & Society's & High \\
\hline 7 & $\begin{array}{c}\text { Prevalence of } \\
\text { the culture of } \\
\text { tribal } \\
\text { solidarity }\end{array}$ & 4.14 & .99 & Society's & High \\
\hline 8 & $\begin{array}{c}\text { Forming } \\
\text { student groups } \\
\text { on the basis of } \\
\text { kinship and } \\
\text { areas }\end{array}$ & 4.05 & 1.07 & Students' & High \\
\hline 9 & $\begin{array}{l}\text { The great } \\
\text { importance } \\
\text { given to the } \\
\text { size of the } \\
\text { family or tribe }\end{array}$ & 4.03 & 1.02 & Society's & High \\
\hline 10 & $\begin{array}{l}\text { Pressure of } \\
\text { some officials } \\
\text { and influential } \\
\text { people to } \\
\text { reduce } \\
\text { punishments } \\
\text { imposed on } \\
\text { students who } \\
\text { resort to } \\
\text { violence }\end{array}$ & 3.99 & 1.06 & Society's & High \\
\hline
\end{tabular}




\begin{tabular}{|c|c|c|c|c|c|}
\hline 11 & $\begin{array}{c}\text { Student } \\
\text { frustration } \\
\text { caused by low } \\
\text { grades }\end{array}$ & 3.98 & 1.09 & Students' & High \\
\hline 12 & $\begin{array}{l}\text { Policy of } \\
\text { exceptions in } \\
\text { university } \\
\text { admissions }\end{array}$ & 3.96 & 1.15 & Universities' & High \\
\hline 13 & $\begin{array}{l}\text { Lack of } \\
\text { concentration } \\
\text { on skills of } \\
\text { critical } \\
\text { thinking and } \\
\text { problem } \\
\text { solving }\end{array}$ & 3.94 & .09 & Universities' & High \\
\hline 14 & $\begin{array}{l}\text { Weak culture } \\
\text { of dialogue }\end{array}$ & 3.92 & 1.01 & Universities' & High \\
\hline 15 & $\begin{array}{c}\text { Lack of } \\
\text { concentration } \\
\text { on the values } \\
\text { of tolerance } \\
\text { and } \\
\text { forgiveness. }\end{array}$ & 3.988 & .93 & Universities' & High \\
\hline
\end{tabular}

The results shown in Table 3 revealed the following:

1) The reasons for university violence mainly belonged to two domains: the reasons related to students, and the reasons related to society. This proved that university violence took place in cultural and social contexts (Roark, 1987). Although university violence was student- and society- centered. some of the responsibility for it fell on universities.

2) The main reasons for violence related to students were: weak commitment to Islamic values, weak resort to psychological and educational counseling, forming student groups on the basis of kinship and areas, and student frustration caused by low grades. This result was in agreement with the results of the studies conducted by Alhawamda (2007), Khamash, Hamdi, and Haddad (2007), Ziadat (2007), and Rawajfa (2007), which showed that tribal and family fanaticism was a main source of university violence.

3) The main reasons for violence related to society were: defending the honor of family or tribe, wrong socialization, tribal support for students who resort to violence, prevalence of the culture of tribal solidarity, the great importance given to the size of the family or tribe, and pressure of some officials and influential people to reduce punishments imposed on students who resort to violence. Such societal reasons indicated that there were social parties that misunderstood tribalism, which can be a unifying and constructive force, and changed it into a destructive factor which contributed to college violence. In other words, the problem was not with tribes, but, it was with exploiting and misrepresenting them.

4) The main reasons for violence related to universities were: policy of exceptions in university admissions, lack of concentration on skills of critical thinking and problem solving, weak culture of dialogue, and lack of concentration on the values of tolerance and forgiveness. The previously mentioned reasons made it clear that universities could not be exempted from the responsibility for violence on their campuses. This result was in agreement with the results of a study done by Ziadat (2007), which showed that eleven, out of thirteen reasons for university violence in Jordan, were related to universities and their administrations. This result could be understood in the light of the fact that Jordanian universities concentrated on indoctrination and memorization, and neglected social skills, dialogue, moral and character education, Islamic values, critical thinking, questioning, discussion and tolerance (Alhawamda, 2007).

On the other hand, to explore whether there were significant differences in the perception of the Hashemite University students of the reasons for university violence due to their sex, college, grade point average and 
university year, the means and standard deviations were calculated, and the One-Way ANOVA analysis was used. This is shown in Table 4.

Table 4. One-Way ANOVA analysis of differences in perception of the reasons for university violence, due to study variables

\begin{tabular}{llllll}
\hline Source & Total Squares & Freedom Degree & Square mean & F value & Sig. \\
\hline Sex & 3.352 & 1 & 3.352 & .180 & .671 \\
College & .475 & 1 & .0475 & 2.558 & .110 \\
Year & .806 & 3 & .269 & 1.446 & .229 \\
GPA & .466 & 2 & .233 & 1.254 & .286 \\
\hline
\end{tabular}

Table 4 shows that there were no differences in the students' perception of the reasons for violence due to differences in the following study variables: sex, college, year and grade point average. This result may be attributed to the fact that the sample's members shared similar conditions, circumstances, and environments, and were affected by similar personal, social and academic experiences. The variables of the study did not make any differences in their view of the causes of students' violence because it was a repeated negative act noticed by students, irrespective of their, sex, academic achievement, majors and university year. So, students did not differ in determining its sources, and the factors that contributed to it.

\section{Recommendations}

In light of the results of the study, the researcher presented the following recommendations to get rid of university students' violence through putting an end to its reasons, and the factors affecting it:

1) Holding conferences, lectures, and seminars about the grave consequences of university violence, and the dangers of tribal and family fanaticism on campus.

2) Offering an obligatory Islamic education course focusing on morals, values, unity, tolerance, dialogue, and peace.

3) Training students for conflict resolution, communication skills, decision making, and critical thinking.

4) Stopping any social support for university violence.

5) Activating university disciplinary laws.

6) Adopting university admissions policies based on justice and equal opportunities.

7) Boosting the role of university educational, social and psychological counselors.

8) Avoiding forming student groups based on tribalism, kinship, bigotry or sectarianism on campus.

9) Avoiding fanatic education and socialization.

10) Conducting studies about university violence and its relation to alienation boredom, authoritarianism, parental care, and value conflict.

\section{References}

Albadayna, T. et al. (2008). Danger Factors at the youth's university environment. National Council for Youth \& Muta University, Jordan.

Alhawamda, K. (2007). Students' Violence at the Jordanian Public and Private universities from the Viewpoints of their Students. Journal of Human Sciences, 12.

Al-Jundi, M. S. (2014). Jordanian Universities Enters the World Ranking from the Gate of Violence. Jordanian Political Science association, Amman, Jordan.

Almakhareez, L. S. (2006). Violence Phenomenon at Jordanian Public Universities (Unpublished doctoral dissertation). Amman Arab University, Amman, Jordan.

Alrawajfa, K. (2007). Violence at Universities. Paper Presented at the Seminar of (Role of Universities in Achieving Comprehensive Security, 12-13, 7, 2007), Centre for Strategic and Security Studies, Amman, Jordan.

Carr, J. L. (2005). American College Health Association Campus Violence White Papers. Baltimore, MD: 
American College Health Association.

Eptein, B. H. (2004). Crisis Intervention on Campus: Current and New Approaches. NASPA Journal, 41(2), 294-316.

Kaplowitz, S. A., \& Campo, S. (2004). Drinking, Alcohol Policy, and Attitudes Toward a Campus Riot. Journal of College Student Development, 45(5), 501-516.

Khamash, M., Hamdi, N., \& Haddad, Y. (2007). University Violence Phenomenon. University of Jordan, Amman, Jordan.

Mahfza, S. (2014). Student Violence in the Jordanian Universities: Causes and Solutions. Jordan Journal of Social Sciences, 7(1).

Marcus, R. et al. (2001). Impersonal Violence Between College Students: Proximal Influences. Paper Presented at the Annual Convention of the American Psychological Association (Washington D.C., August 4-8).

Miller, M., Hemenway, D., \& Wechsler, H. (1999). Guns at College. Journal of American College Health, 48(1), 6-7.

Pezza, P. E., \& Pellotti, A. (1995). College Campus Violence: Origins, Impacts and Responses. Educational Psychology Review, 7(1).

Report of the Committee on Campus Violence. (1997). The John Hopkins University, Baltimore, MD., U.S.A.

Roark, M. L. (1987). Preventing Violence on College Campuses. Journal of Counseling \& Development, 65(7), 367-371

Santucci, K., \& Gable, R. K. (1998). Student Perception of Campus Safety at a Large Rural University. Paper Presented at the Annual Meeting of the Northeastern Research Association (Ellenville, N.Y, Oct., 1997).

Wessler, S., \& Moss, M. (2001). Hate Crimes on Campus: The Problem and Efforts to Confront It. Department of Justice, Washington D.C, Bureau of Justice Assistance.

Ziadat, A. (2007). A Poll about University Riot. Yarmouk University, Jordan.

\section{Copyrights}

Copyright for this article is retained by the author(s), with first publication rights granted to the journal.

This is an open-access article distributed under the terms and conditions of the Creative Commons Attribution license (http://creativecommons.org/licenses/by/3.0/). 